\title{
CARBON ISOTOPE CHANGE AS AN INDICATOR OF BIOMASS FLUX AND AN AID TO CORRELATION DURING LUDENSIS- NILSSONI (SILURIAN) TIME
}

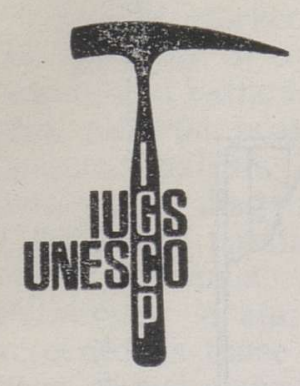

Project 216 Global Bioevents

\begin{abstract}
Whole-rock $\delta^{13} \mathrm{C}$ data have been obtained from six sites in rocks straddling the Wenlock-Ludlow (Silurian) boundary in the Anglo-Welsh area, across a transect from shelf to basin. There are two ${ }^{13} \mathrm{C}$ depletions during this time: a steep one during the nassa Biozone recognized at Builth (and possibly the West Midlands), and a gentler decline across the ludensis Biozone (Wenlock) into the nilssoni Biozone (Ludlow) recognized in all sites. These depletions coincide with decline/extinction events in the pelagic graptolite record.

The $\delta^{13} \mathrm{C}$ curves, also, offer the possibility in the Silurian of being used for chemostratigraphic correlation, thus both adding to existing biostratigraphic data, and also suggesting tie-lines where faunal control is found wanting. Correlation of the Much Wenlock Limestone Formation may be enhanced by this method.
\end{abstract}

\section{Introduction}

Carbon isotope stratigraphy is becoming a widely used correlation tool in marine sequences from a variety of time intervals. Scholle and Arthur (1980) first demonstrated its utility in Mesozoic and early Cenozoic rocks. More recently others have applied it to the study of older rocks, for example the Palaeozoic-Mesozoic transition (e. g. Magaritz et al., 1988; Magaritz and Holser, 1991) as well as the Precambrian-Cambrian transition (Brasier et al., 1990; Kirschvink et al., 1991; Magaritz et al., 1986; Magaritz et al., 1991).

No high resolution whole-rock $\delta^{13} \mathrm{C}$ data have been forthcoming from strata of Silurian age. Those carbon isotope measurements which have been made on rocks of this age have concentrated on diagenetic aspects (e. g. Rowse, 1987) or have addressed general Palaeozoic palaeoceanographic and stratigraphic questions using brachiopod shells (e.g. Wadleigh and Veizer, 1992). Our aim in this study has been to investigate whether any systematic changes in $\delta^{13} \mathrm{C}$ as measured in whole rock occur across Wenlock-Ludlow boundary sections in Wales and the Welsh Borderland, including the type areas for the Wenlock and Ludlow series. These boundary sections include the lundgreni to nilssoni graptolite biozones interval. If such changes occur, can they be related to faunal change as is the case in younger horizons (e.g. the $\mathrm{K}-\mathrm{T}$ and $\mathrm{P}-\mathrm{T}$ boundary crises)? Also can isotope curves serve, in the Silurian, as a supplementary or even more refined means of correlation between sections additional to that of biostratigraphy?

* Department of Earth Sciences, University of Oxford, Parks Road, Oxford OX1 3PR, U. K.

** Geological Collections, University Museum, University of Oxford, Parks Road, Oxford OX1 3PW, U. K.

(C) Eesti TA Toimetised, Geoloogia, 1992 


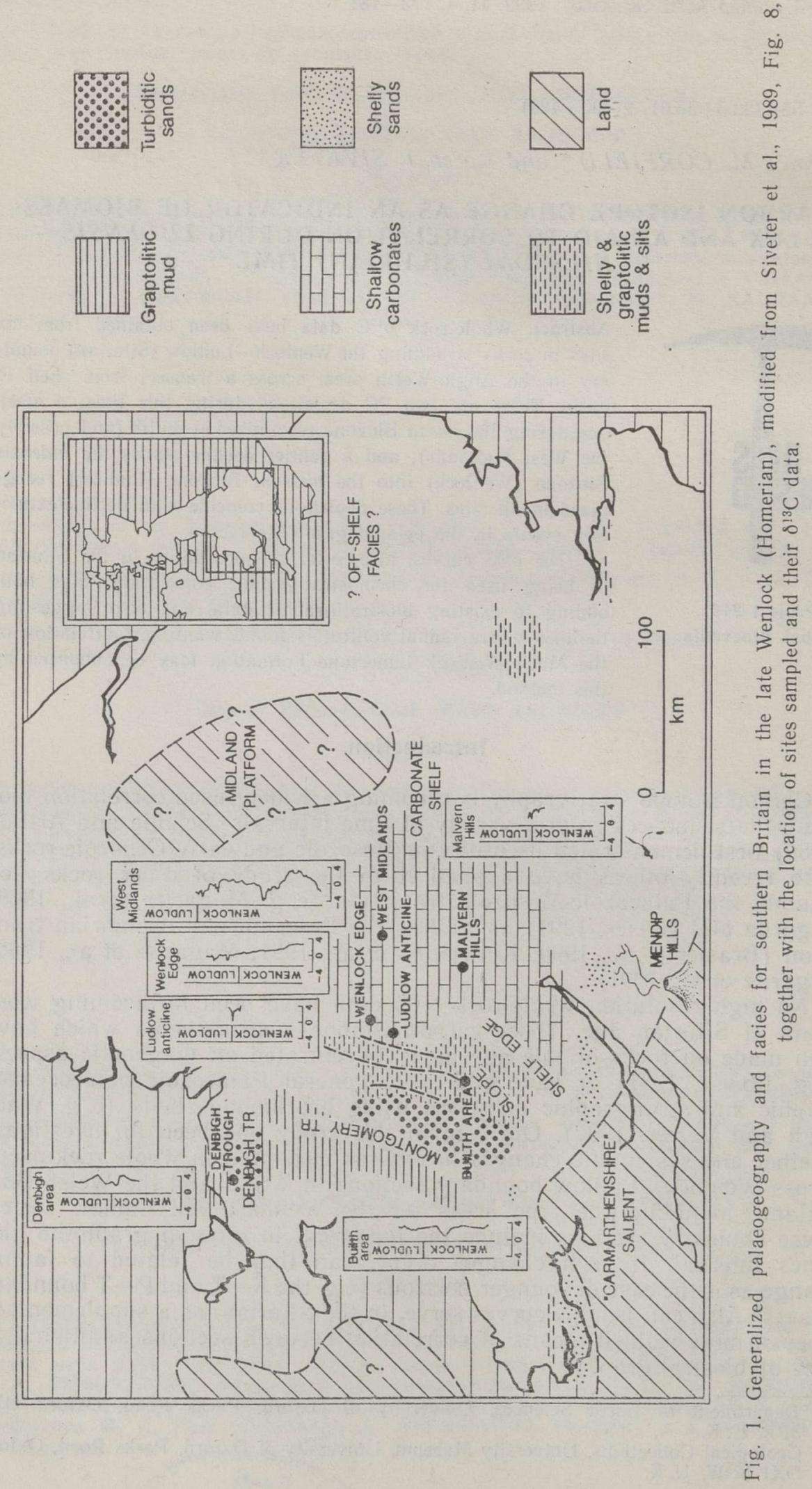




\section{Sites and Methods}

The sites sampled (Fig. 1) occur over a transect which includes shallow marine facies on a carbonate platform area (the West Midlands of England; the Wenlock Edge to Ludlow area; the Malvern Hills), to more offshore shelf-edge/slope deposits (Builth area), to fully graptolitic shales deposited more nearly in the centre of the Welsh Basin (Denbighshire).

The sampling interval employed ranged from $10 \mathrm{~cm}$ close to the Wenlock-Ludlow boundary to $1 \mathrm{~m}$ further up- and down-section. Samples for isotopic analysis were drilled from the matrix of a freshly broken face of rock using a vibrotool. Obvious vugs and veins within the rock were avoided.

Several workers (e. g. Brand and Veizer, 1980, 1981) have stressed the necessity of applying optical (microscopic, scanning electron microscopic, and cathodoluminescence) as well as geochemical (atomic absorption, electron probe) screening techniques to $\mathrm{Palaeozoic}$ rocks prior to isotopic analysis, in order to remove samples suspected of being contaminated by diagenetic overprinting. More recently, Wadleigh and Veizer (1992) have pointed out inconsistencies in the application of $\delta^{13} \mathrm{C}$ stratigraphy in Cenozoic and Mesozoic rocks compared to its application in Palaeozoic strata; in the former, samples are usually not as avidly screened as those from the latter where samples are considered to have been so pervasively altered as to be, in nearly all cases, unusable. We have chosen to experiment with whole-rock analyses to assess the effectiveness of this technique (which is widely used in younger sedimentary sequences) as a monitor of carbon flux and therefore a potential correlation tool in the Silurian. We consider that, if a sufficient number of measurements are made from a variety of coeval sites, then the balance of probabilities will indicate whether diagenesis is likely to have been an important contributor to the overall isotopic signal. However, in order to provide an independent check on our results we have performed major and minor elemental abundance measurements on samples taken from a section (Lower Hall Farm Quarry) which exhibits the representative signal (Corfield et al., 1992).

\section{Isotope Curves and Faunal Change}

At present we regard the occurrence of a systematic $\delta^{13} \mathrm{C}$ decline across all six of the Wenlock-Ludlow boundary sections analysed to date (Figs. 1 and 2) as an indication that the isotope change recorded reflects palaeoceanographic change on at least a regional, sedimentary basin scale rather than reflecting local diagenesis.

Our data (Fig. 2) show an approximately monotonic decline in the $\delta^{13} \mathrm{C}$ of whole-rock samples from the uppermost Wenlock into the basal Ludlow. This depletion occurs in carbonate shelf environments (the West Midlands; Wenlock Edge; the Ludlow anticline; the Malvern Hills) as well as more offshore, deeper water facies (Builth area). Our data also show another, steeper $\delta^{13} \mathrm{C}$ decline slightly lower in the upper Wenlock, in the West Midlands and Builth sections.

Following the work of Elles (1900) in particular, and the stratigraphically overlapping study of Wood (1900), the Builth area has come to be regarded as the type area for the Wenlock graptolite sequence in the Welsh Basin. More recently, the unpublished revision of Harris (1987) has shown that in the River Irfon section the nassa Biozone begins some $10 \mathrm{~m}$ below the base of the Ludlow and that here this biozone is $1.75-2 \mathrm{~m}$ thick. 


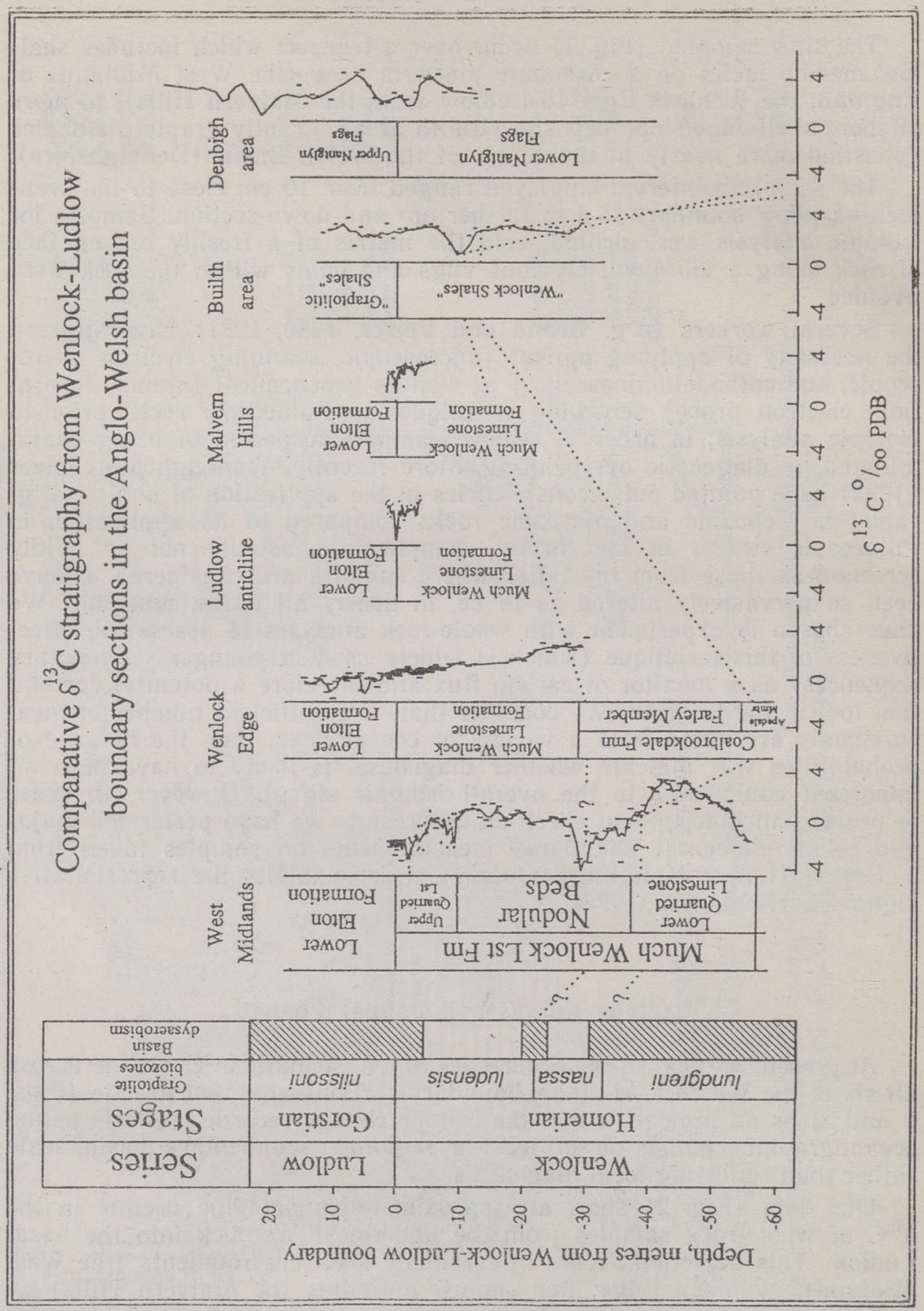


The stratigraphically lower ${ }^{13} \mathrm{C}$ depletion mentioned above coincides in the River Irfon section with the nassa Biozone. We note the recent zonal refinement in Thuringia and elsewhere by Jaeger (1991) of the end-lundgreni to ludensis interval into four biozones, but usage herein of the nassa biozone for this interval in the UK reflects the presently recognized scheme for the British sequence.

As a result of the end-lundgreni graptolite extinctions, a major, global decline in pelagic graptolite species diversity occurred in the time represented by the nassa Biozone, with just one or two species surviving the end-lundgreni crisis (Jaeger, 1991; Koren, 1987, 1991; Koren and Rickards, 1980; Rickards, 1989). There is also now detailed evidence emerging from at least Central Asia (Ural-Novaya Zemlya; Koren, 1991, Fig. 2) and Thuringia (Jaeger, 1991, Fig. 1), that in overall terms graptolite species diversity began to recover from the end of the nassa Biozone until some way into (Thuringia) or the end of (Central Asia) the ludensis Biozone when there was another decline (Thuringia) or extinction event (Central Asia), though this was of lesser magnitude than that at end of the lundgreni Biozone; thereafter pelagic graptolites, overall, underwent a radiation phase from the base of the nilssoni Biozone up into the Gorstian.

We have suggested (Corfield et al., 1992) that the stratigraphically lower ${ }^{13} \mathrm{C}$ depletion noted in the River Irfon section may be the expression in the whole-rock carbon isotope record of the nassa Biozone diversity decline. Higher in this section, $\delta^{13} \mathrm{C}$ values recover to intermediate values before declining once more across the Wenlock-Ludlow boundary. We further suggested (Corfield et al., 1992), given the very short time interval associated with the sections investigated (about $1-2$ my; see below), that the two episodes of carbon isotope depletion may represent two aspects of the same phenomenon, and that the graptolite diversity decline may be a stepped process, this being reflected in the shape of the $\delta^{13} \mathrm{C}$ decline. The very detailed biozonation recently obtained for the late Wenlock-early Ludlow graptolite sequences in Thuringia and Central Asia (see above) has not yet been accomplished for the British sequence; however the immediately post-nassa Biozone evidence from the former two areas, of overall recovery followed by a lesser ludensis decline/extinction, is compatible with the $\delta^{13} \mathrm{C}$ curve obtained for the Builth, and possibly (see below) the West Midlands sections, and the curve obtained from all British sections across the Wenlock-Ludlow boundary.

Fig. 2. ${ }^{13} \mathrm{C}$ data and correlation ties for the localities sampled: The West Midlands; trench and quarry face, eastern side of Wren's Nest hill, Dudley (Grid ref. SO 93829220. See Butler, 1939; Bassett, 1974, 1976; Cutler et al., 1990). Wenlock Edge; Shadwell Rock Quarry, Much Wenlock (Grid ref. SJ 6262 0081. See Shergold and Bassett, 1970; Hurst, 1975; Bassett, 1976). Ludlow anticline; quarry at Pitch Coppice, $4 \mathrm{~km} \mathrm{SW}$ of Ludlow (Grid ref. SO 4726 7301. See Lawson and White, 1989). Malvern Hills; Lower Hall Farm (=Gurney's) Quarry, $1 \mathrm{~km} \mathrm{NE}$ of Ledbury (Grid ref. SO 7175 3835. See Penn and French, 1971). Builth area; eastern side of the River Irfon, Builth Wells (Grid ref. SO 0322 5082. See Elles, 1900; Wood, 1900; Harris, 1987; Siveter et al., 1989). Denbigh section; stream section near Ty Mawr farm, $6.5 \mathrm{~km}$ NNE of Llanwrst (Grid ref. SH 8230 6846. See Holland et al., 1969; Warren et al., 1984).

The basin dysaerobism data, including recognition of the two late Wenlock oxic events (indicated by lack of diagonal ornament), are taken from Kemp (1991). The position of the G. nassa Biozone at Builth is based on Harris (1987), and its position at Wenlock Edge on Bassett et al. (1975). The strata which possibly correspond to the nassa Biozone in the West Midlands are correlated with the Builth section on the basis of the ${ }^{13} \mathrm{C}$ curves. To highlight $\delta^{13} \mathrm{C}$ trends, the raw data have been filtered with a three point moving average. 
Our initial work in the Silurian suggests a similarity with certain other studies from different parts of the stratigraphic column (e. g. Magaritz et al., 1986; Magaritz et al., 1988), that show a correlation between faunal turnover and intervals of ${ }^{13} \mathrm{C}$ depletion, which are sometimes also at or close to major chronostratigraphic boundaries. If it is correct to link the two pulses of reduced graptolite diversity with the two intervals of $\delta^{13} \mathrm{C}$ decline, then the implication is that carbon isotope and biomass change are linked in the Silurian in the same way that has been suggested for, for example, the Cretaceous-Tertiary boundary (e. g. Perch-Nielsen et al., 1982). Hence it may be a general axiom of the geological record that the history of the diversity and biomass of pelagic taxa, as diverse as Cenozoic nannofossils and Palaeozoic graptolites, may be chronicled in the sedimentary $\delta^{13} \mathrm{C}$ record.

In terms of amplitude the $\delta^{13} \mathrm{C}$ depletion straddling the Wenlock-Ludlow boundary is approximately $4 \% 0$ in the sections analysed. Current estimates (see below) suggest that the section in the West Midlands is about 2 my or less in duration. The resulting minimum rate of $\delta^{13} \mathrm{C}$ decline of about $8 \% \mathrm{o} / \mathrm{my}$ is therefore comparable with the rate of $\delta^{13} \mathrm{C}$ depletion at the Cretaceous-Tertiary boundary (between $15 \%$ my at Deep Sea Drilling Project holes on the Walvis Ridge (Shackleton and Hall, 1984) to $5 \% \mathrm{o} / \mathrm{my}$ in the Bottaccione Gorge, Italy (Corfield et al., 1991)). As is well known, at the latter horizon there is a major episode of marine and terrestrial extinction.

Extinction and reduced productivity in the marine realm have palaeoceanographic implications. Reduced productivity may lead to a decrease in the depth and intensity of the oxygen minimum zone in an analogous manner to that suggested for other intervals of profound carbon isotope depletion. On the basis of sedimentological data, Kemp (1991) has identified two major intervals of increased basin ventilation in late Wenlock times in the Iapetus Ocean. He suggested that that late Wenlock 'oxic' event comprised two sub-events when at least the Iapetus Ocean basin was flushed with relatively more oxygenated waters. These oxic events coincided with intervals of eustatic sea-level low stand and increased carbonate deposition on the shelves and were suggested by him to be the result of enhanced deeper water circulation.

Both oxic events identified by Kemp appear to correlate with the two episodes of $\delta^{13} \mathrm{C}$ depletion documented in Figs. 1 and 2. Kemp (1991) was unable to distinguish between reduced primary productivity or increased deep water ventilation to account for his suggested oxic intervals. We suggest that the late Wenlock graptolite extinctions are implicated in the generation of the oxic events and that accordingly greater emphasis should be placed on the reduced productivity hypothesis.

\section{Correlation}

Carbon isotope stratigraphy, like magnetostratigraphy, is an iterative rather than an ordinal method of correlation. Hence it is only of use if it can be applied within an existing framework of correlation which constrains the inflections of the carbon isotope curve to a limited interval of time. In the case of the Silurian, Zalasiewicz (1990) has suggested that the global zonal scheme for this system based on graptolites yields an average duration of about 0.8 my per biozone, and potential further biostratigraphical refinement suggests the possibility at certain horizons of reducing units of correlation using these fossils to at least $0.1-0.2$ my (Rickards, 1989). If systematic $\delta^{13} \mathrm{C}$ changes undistorted by diagenesis can be retrieved from Silurian rocks, and these tied into the graptolite 
biostratigraphy, they offer the potential to complement this biozonation and to refine the degree of resolution offered by some, at least, of the graptolite biozones. Further, graptolites are lacking in some Silurian sequences, particularly in carbonate rocks. An isotope signature for the Silurian could in such circumstances suggest correlation ties where faunal control is found wanting (e.g. much of the Much Wenlock Limestone Formation).

The stratigraphically lower $\delta^{13} \mathrm{C}$ depletion in the West Midlands may be the correlative of the earlier nassa Biozone depletion at Builth. If so, better stratigraphical precision will have been achieved for this carbonate sequence, the precise position of which has been uncertain with respect to several of the late Wenlock graptolite biozones (Bassett, 1974, 1976).

In order to fully appreciate the significance of the $\delta^{13} \mathrm{C}$ minima near the Wenlock-Ludlow boundary we need to establish the carbon isotope variability of adjacent strata. In addition we wish to examine other Silurian sections from both within and outside the Welsh Basin to assess more the potential of $\delta^{13} \mathrm{C}$ stratigraphy for intra- and interbasinal correlation. Finally, we regard our data as preliminary, pending further usage and testing of the methods employed on Silurian strata.

Acknowledgements. We thank the following who have, variously, assisted with the fieldwork localities, discussion, and release of unpublished information associated with this paper at various stages of its preparation: Dick Aldridge, Mike Bassett, Mike Durkin, Chris Fletcher, John Harris, Dimitri Kaljo, Alan Kemp, Jim Marshall, Barrie Rickards, David Siveter, Steve Tunnicliffe, Peter Warren, and Bill Berry.

\section{REFERENCES}

Bassett, M. G. 1974. Review of the stratigraphy of the Wenlock Series in the Welsh Borderland and South Wales. - Palaeontology, 17, 745-777.

Bassett, M. G. 1976. A critique of diachronism, community distribution and correlation at the Wenlock-Ludlow Boundary. - Lethaia, 9, 207-218.

Bassett, M. G., Cocks, L. R. M., Holland, C. H., Rickards, R. B. and Warren, P. T. 1975. The Type Wenlock Series. Rep. Inst. Geol. Sci., 75/13.

Brand, U. and Veizer, J. 1980. Chemical diagenesis of a multicomponent carbonate system, 1: Trace elements. - J. Sediment. Petrol., 50, 1219-1236.

Brand, U. and Veizer, J. 1981. Chemical diagenesis of a multicomponent carbonate system, 2: Stable isotopes. - J. Sediment. Petrol., 51, 987-997.

Brasier, M. D., Magaritz, M., Corfield, R. M., Luo Huilin, Wu Xiche, Ouyand Lin, Jiang Zhiwen, Hamdi, B., He Tinggui and Fraser, A. G. 1990. The carbon- and oxygenisotope record of the Precambrian-Cambrian boundary interval in China and Iran and their correlation. - Geol. Mag., 127, 319-332.

Butler, A. J. 1939. The stratigraphy of the Wenlock Limestone of Dudley. - Quart. J. Geol. Soc. London, 95, 37-74.

Corfield, R. M., Cartlidge, J. E., Premoli-Silva, I. and Housley, R. A. 1991. Oxygen and carbon isotope stratigraphy of the Palaeogene and Cretaceous limestones in the Bottaccione Gorge and the Contessa Highway sections, Umbria, Italy. - Terra Nova, $3,414-422$.

Corfield, R. M., Siveter, D. J., Cartlidge, J. E. and McKerrow, S. 1992. Carbon isotope excursion near the Wenlock-Ludlow (Silurian) Boundary in the Anglo-Welsh Area. - Geology, 20, 371-374.

Cutler, A., Oliver, F. G. and Reid, C. G. R. 1990. Wren's Nest National Nature Reserve; Geological Handbook and Field Guide. Dudley Leisure Services and Nature Conservancy Council. 
Elles, G. L. 1900. The zonal classification of the Wenlock Shales of the Welsh Borderland. - Quart. J. Geol. Soc. London, 56, 370-414.

Harris, J. H. 1987. The geology of the Wenlock Shales around Builth Wells. Unpublished $\mathrm{Ph}$. D. thesis, University of Cambridge.

Holland, C. H., Rickards, R. B. and Warren, P. T. 1969. The Wenlock graptolites of the Ludlow district, Shropshire and their stratigraphical significance. - Palaeontology, 12, 663-683.

Hurst, J. M. 1975. The diachronism of the Wenlock Limestone. - Lethaia, 8, 301-314.

Jaeger, H. 1991. Neue standard-Graptolithenzonen folge nach der "Großen Krise" an der Wenlock/Ludlow-Grenze (Silur). - Neues Jahrb. Geol. und Paläontol., Abhandlungen, 182, 303-354.

Kemp, A. E. S. 1991. Mid-Silurian pelagic and hemipelagic sedimentation and palaeoceanography. - In: M. G. Bassett, P. D. Lane and D. Edwards (eds.). The Murchison Symposium: Proc. Intern. Conf. on the Silurian System. Spec. Papers in Palaeontology, 14, 261-299.

Kirschvink, J. L., Magaritz, M., Ripperdan, R. L., Zhuravlev, A. Yu. and Rozanov, A. Yu. 1991. The Precambrian/Cambrian boundary: Magnetostratigraphy and carbon isotopes resolve correlation problems between Siberia, Morocco, and South China. - GSA Today, 1, 69-87.

Koren, T. 1987. Graptolite dynamics in Silurian and Devonian time. - Bull. Geol. Soc. Denmark, 35, 149-159.

Koren, T. 1991. The lundgreni extinction event in Central Asia and its bearing on graptolite biochronology within the Homerian. - Proc. Estonian Acad. Sci. Geol., $40,2,74-78$.

Koren, T. N. and Rickards, R. B. 1980 (for 1979). Extinction of the graptolites. - In: A. L. Harris, C. H. Holland and B. E. Leake (eds.). The Caledonides of the British Isles reviewed. Spec. Publ. Geol. Soc. London, 8, 457-466.

Lawson, J. D. and White, D. E. 1989. The Ludlow Series in the Ludlow area. - In: C. H. Holland and M. G. Bassett (eds.). A Global Standard for the Silurian System. National Museum of Wales, Geol. Ser., 9. Cardiff, 73-90.

Magaritz, M., Bar, R., Baud, A. and Holser, W. T. 1988. The carbon-isotope shift at the Permian-Triassic boundary in the Southern Alps is gradual. - Nature, 331, 337-339.

Magaritz, M. and Holser, W. T. 1991. The Permian-Triassic of the Gartnerkofel-1 core (Carnic Alps, Austria): Carbon and oxygen isotope variation. - In: W. T. Holser and H. P. Schönlaub (eds.). The Permian-Triassic Boundary in the Carnic Alps of Austria (Gartnerkofel Region). Abhandlungen der Geologischen Bundesanstalt, Band 45. Vienna, 149-163.

Magaritz, M., Holser, W. T. and Kirschvink, J. L. 1986. Carbon isotope events across the Precambrian-Cambrian boundary on the Siberian platform. - Nature, 320, 258-259.

Magaritz, M., Kirschvink, J. L., Latham, A. J., Zhuravlev, A. Yu, and Rozanov, A. Yu. 1991. Precambrian/Cambrian boundary problem: Carbon isotope correlations for Vendian and Tommotian time between Siberia and Morocco. - Geology, 19, $847-850$.

Penn, J. S. W. and Frenck, J. 1971. The Malvern Hills. Geologists' Association Guide, $4,1-36$.

Perch-Nielsen, K., McKenzie, J., and He, Q. 1982. Biostratigraphy and isotope stratigraphy and the 'catastrophic' extinction of calcareous nannoplankton at the Cretaceous/Tertiary boundary. - Spec. Paper Geol. Soc. America, 190, 353-371.

Rickards, R. B. 1989. Exploitation of graptolite cladogenesis in Silurian stratigraphy. In: C. H. Holland and M. G. Bassett (eds.). A Global Standard for the Silurian System. National Museum of Wales, Geol. Ser., 9. Cardiff, 267-274.

Rowse, M. J. 1987. The diagenesis and geochemistry of Silurian limestones, Welsh Borderlands. Unpublished $\mathrm{Ph}$. D. thesis, University of Liverpool. 
Scholle, P. A. and Arthur, M. A. 1980. Carbon isotope fluctuations in Cretaceous pelagic limestones: Potential stratigraphic and petroleum exploration tool. - Amer. Assoc. Petrol. Geol. Bull., 64, 67-87.

Shackleton, N. J. and Hall, M. A. 1984. Carbon isotope data from Leg 74 sediments. In: T. C. Moore, Jr., P. D. Rabinowitz et al. (eds.). Initial Reports of the Deep Sea Drilling Project, 74. U. S. Government Printing Office, Washington D.C., 613-619.

Shergold, J. H. and Bassett, M. G. 1970. Facies and faunas at the Wenlock/Ludlow boundary of Wenlock Edge Shropshire. - Lethaia, 3, 113-142.

Siveter, D. J., Owens, R. M. and Thomas, A. T. 1989. Silurian Field Excursions: A Geotraverse across Wales and the Welsh Borderland. National Museum of Wales, Geol. Ser., 10. Cardiff.

Wadleigh, M. A. and Veizer, J. $1992 .{ }^{18} \mathrm{O} /{ }^{16} \mathrm{O}$ and ${ }^{13} \mathrm{C} /{ }^{12} \mathrm{C}$ in lower Paleozoic articulate brachiopods: Implication for the isotopic composition of seawater. - Geochim. Cosmochim. Acta, 56, 431-443.

Warren, P. T., Price, D., Nutt, M. J. C. and Smith, E. G. 1984. Geology of the Country around Rhyl and Denbigh. Memoir of the British Geological Survey.

Wood, E. M. R. 1900. The Lower Ludlow Formation and its graptolite fauna. - Quart. J. Geol. Soc. London, 56, 415-492.

Zalasiewicz, J. A. 1990. Silurian graptolite biostratigraphy in the Welsh Basin. - J. Geol. Soc. London, 147, 619-622.

Presented by D. Kaljo

Received

April 30, 1992

Richard M. CORFIELD, Derek J. SIVETER

\section{SUSINIKU ISOTOOPIDE SISALDUS KUI BIOMASSI INDIKAATOR JA VAHEND KORRELATSIOONIKS LUDENSIS-NILSSONI TSOONIDE (SILUR) VAHEMIKUS}

Inglise ja Walesi ala läbilõigetes täheldatakse Wenlocki-Ludlow' piiri läheduses kahte $\delta^{13} \mathrm{C}$ kõvera selget langust, mida seotakse graptoliitide kiire väljasuremisega ning vastavaid tasemeid kasutatakse profiilide korreleerimisel.

Ричард М. КОРФИЛД, Дерек Дж. СИВЕТЕР

\section{СОДЕРЖАНИЕ ИЗОТОПОВ УГЛЕРОДА КАК ИНДИКАТОР БИОМАССЫ И СРЕДСТВО КОРРЕЛЯЦИИ В ИНТЕРВАЛЕ ЗОН LUDENSIS-NILSSONI (С ИЛУР)}

В разрезах Уэльса и Западной Англии на границе венлока и лудлова установлено два понижения кривой $\delta^{13} \mathrm{C}$, что связывается с биотическими событиями тех времен - с вымиранием граптолитов на определенных уровнях. Эти уровни используются при обосновании корреляции разрезов. 